\title{
Keteladanan Pengasuh dan Peran Orang Tua dalam Pembentukan Karakter Santri Tarbiyatul Athfal Tegalrejo Magelang
}

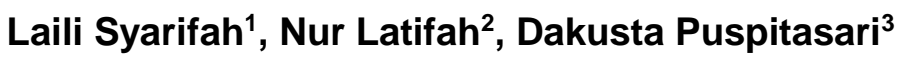 \\ 1,3STAI AI Husain Magelang, ${ }^{2}$ IAINU Kebumen \\ lailis@staia-sw.ac.id
}

\section{Article History}

received 20/5/2021

revised $21 / 6 / 2021$

accepted 28/6/2021

\begin{abstract}
Caregivers or kiai in the boarding school have a central role in the process of forming the character of students, but this role cannot run optimally if there is no parental involvement. The purpose of this study was to find out how the role of caregivers and parents in forming the character of Tarbiyatul Athfal students. The method used in this research is qualitative research with a case study research design. The collection technique in this study uses interviews, observation, and documentation. The data obtained is then analyzed by data reduction techniques, data presentation, and data verification. The results of this study prove that the exemplary caregivers of Tarbiyatul Athfal Islamic boarding schools include 1) respect, 2) patience and steadfastness, 3) hard work, 4) modesty, and 5) tawakal. Parental can also play a role in character building 1) exemplary and 2) habituation. The results of this study indicate that parents carry out character education through educational and religious functions. The conclusion of this study is that both caregivers and parents have a role in the process of character education for students.
\end{abstract}

Keywords: Exemplary, the role of Parents, Character, Boarding school

\begin{abstract}
Abstrak
Pengasuh atau kiai dalam pondok pesantren memiliki peranan sentral dalam proses pembentukan karakter santri, namun peranan tersebut tidak dapat berjalan maksimal jika tidak ada keterlibatan orang tua. Tujuan dari penelitian ini adalah untuk mengetahui bagaimana peranan pengasuh dan orang tua dalam pembentukan karakter santri Tarbiyatul Athfal. Metode yang digunakan dalam penelitian ini adalah penelitian kualitatif dengan desain penelitian studi kasus. Teknik pengumpulan pada penelitian ini menggunakan wawancara, observasi, dan dokumentasi. Data yang diperoleh kemudian dianalisis dengan teknik reduksi data, penyajian data, dan verifikasi data. Hasil dari penelitian ini membuktikan bahwa keteladanan pengasuh pondok pesantren Tarbiyatul Athfal yang meliputi 1) rasa hormat, 2) sabar dan tabah, 3) kerja keras, 4) sederhana dan 5) tawakal. Orang juga dapat berperan dalam pembentukan karakter berupa 1) keteladanan dan 2) pembiasaan. Hasil dari penelitian ini menunjukkan bahwa orang tua melaksanakan pendidikan karakter melalu fungsi pendidikan dan fungsi religius. Kesimpulan dari penelitian ini adalah baik pengasuh maupun orang tua memiliki peranan dalam proses pendidikan karakter santri.
\end{abstract}

Kata kunci: Keteladanan, peran orang tua, karakter, Pesantren 


\section{PENDAHULUAN}

Penanaman akhlak sejak dini pada setiap anak dapat dilakukan dengan melaksanakan pendidikan karakter (Elsap, 2018). Pendidikan karakter merupakan penanaman nilai-nilai dasar yang harus diresapi untuk mewujudkan kedamaian ditengah-tengah masyarakat. Nilai-nilai karakter yang harus ditanamkan pada peserta didik adalah kebijaksanaan, saling menghormati, bertanggungjawab dan lain sebagainya (Koesoema, 2007). Sementara itu menurut Departemen Pendidikan Nasional (2010) nilai-nilai yang terkandung dalam pendidikan karakter adalah religius, produktif, nasionalis, dan kreatif.

Pendidikan karakter sangat penting untuk diperhatikan pada saat ini, hal ini dikarenakan banyaknya kasus-kasus menyimpang yang dilakukan oleh para pelajar. Misalnya, terlibat dalam penyalahgunaan narkoba, pergaulan bebas, tawuran bahkan melakukan premanisme (Kosim, 2011). Perilaku menyimpang dari kalangan pelajar juga terjadi di Kabupaten Magelang Jawa Tengah. Pada tanggal 31 Januari 2019 terjadi tawuran yang melibatkan 30 siswa, dan menyebabkan korban jiwa (Antara, 2019). Masih ada kasus-kasus lain yang seharusnya tidak dilakukan oleh seorang peserta didik.

Dari kondisi tersebut menunjukkan bahwa pendidikan karakter sangat penting untuk dilakukan. Thomas Lickona (2016) menyatakan bahwa meningkatnya kasuskasus kekerasan yang dilakukan remaja merupakan salah satu tanda sebuah bangsa sedang menuju jurang kehancuran. Melihat realitas yang saat ini banyak melibatkan kalangan remaja (pelajar) maka perlu mendapatkan perhatian khusus dari stakeholder pendidikan di Indonesia. Merebaknya kasus-kasus yang melibatkan peserta didik ini disinyalir bahwa pendidikan yang ada selama ini hanya menjadi tempat untuk transfer pengetahuan saja, belum menyentuh pada aspek pembentukan karakter (Syafe'i, 2017).

Pada kondisi inilah yang membuat banyak orang tua memilih pondok pesantren sebagai tempat melangsung pendidikan anak-anaknya. Sebagai subsistem pendidikan nasional, pondok pesantren dipandang lebih unggul dalam hal pembentukan karakter para peserta didik (santri). Hal ini dapat dilihat dari hasil penelitian yang dilakukan oleh Kurniawan (2015) bahwa pelaksanaan pendidikan karakter di pondok pesantren dapat berjalan dengan baik karena adanya tahapan moral knowing, moral feeling dan moral action. Demikian halnya penelitian yang dilakukan oleh Saihu \& Rohman (2019) bahwa proses pembelajaran peserta didik di pondok pesantren mencerminkan pengembangan karakter melalui sikap saling menghormati, keikhlasan, persaudaraan ketaatan dan kesederhanaan.

Salah satu pondok pesantren yang berupaya membentuk karakter para santrinya adalah pondok pesantren Tarbiyatul Athfal Tegalrejo di Kabupaten Magelang. Pondok yang di kembangkan oleh putri pertama K.H Mudrik Chudlori dan Nyai Hj. Nafisatul Khoridah yaitu Nyai Nur Chafsoh ini mendidik anak-anak agar bisa terlatih menjadi pribadi yang mandiri semenjak usia dini. Mereka tidak hanya memperdalam ilmu agama tetapi juga mempelajari pendidikan formal atau dengan metode pembelajaran home schooling. Pondok pesantren Tarbiyatul Athfal Tegalrejo mempunyai konsep sendiri dalam memberikan pendidikan formal untuk santri-santrinya. Hal itu dilakukan agar kelak menjadi generasi penerus yang beriman, beradab, dan berakhlaqul karimah serta memiliki kecerdasan intelektual. Upaya pembentukan karakter para santrinya dapat dilihat dari visi dari pondok pesantren Tarbiyatul Athfal Tegalrejo yaitu "Mewujudkan muslim yang bertakwa kepada Allah SWT dan berakhlaqul Karimah".

Karakter bukanlah terbentuk sejak lahir atau menjadi sifat bawaan, tetapi melalui sebuah proses (Mulyahati \& Fransyaigu, 2018). Karakter akan terbentuk melalui interaksi peserta didik dengan lingkungan mulai dari keluarga, masyarakat dan juga lingkungan pendidikan/sekolah/pesantren. Dengan demikian salah faktor yang dapat mempengaruhi karakter adalah lingkungan keluarga dalam hal ini adalah orang tua, 
karena keluarga sangat berperan dalam membentuk watak, kepribadian, nilai-nilai budaya, nilai-nilai keagamaan dan moral (Muhaimin, 2017). Lebih lanjut Elsap (2018) menyatakan bahwa keluarga merupakan pendidikan pertama dalam pembinaan karakter untuk anak. Selain itu keluarga juga merupakan sumber pendidikan moral yang paling utama bagi anak-anak (Lickona, 2016). Dengan demikian tidak terbantahkan lagi bahwa pendidikan karakter tidak hanya menjadi tanggungjawab sekolah tetapi juga pada keluarga.

Hasil penelitian yang dilakukan oleh Handayani, Soesilowati, \& Priyanto (2018) menyimpulkan bahwa lingkungan keluarga berkontribusi sebesar 83,0\% dalam pembentukan karakter peserta didik. Keluarga memiliki peran penting dalam pembentukan akhlakul karimah. Keluarga akan membentuk karakter peserta didik dan akan berpengaruh terhadap lingkungannya (Rosikum, 2018). Demikian hasil studi yang dilakukan oleh Desforges \& Abouchaar (2003) keterlibatan orang tua memiliki peranan penting dalam pendidikan karakter karena berkontribusi dalam penyediaan lingkungan yang aman dan stabil, stimulasi intelektual, diskusi orang tua-anak, model yang baik dari nilai-nilai sosial dan pendidikan yang konstruktif dan aspirasi yang tinggi terkait untuk pemenuhan pribadi dan kewarganegaraan yang baik.

Selain dukungan orang tua pendidikan karakter juga dapat diberikan dilingkungan pendidikan melalui keteladanan. Keteladanan pada konteks penelitian ini tentu saja keteladanan dari pengasuh pondok Tarbiyatul Athfal Tegalrejo, Magelang. Keteladanan pengasuh berperan penting karena pengasuh merupakan figur sentral dalam pendidikan pesantren, sehingga semua tindakan dan perkataannya menjadi panutan bagi seluruh stakeholder pondok pesantren termasuk para peserta didiknya (Saihu \& Rohman, 2019). Keteladanan tidak hanya memberi contoh namun juga sebagai penguat moral bagi para peserta didik dalam berperilaku dan bersikap (Prasetyo, Marzuki, \& Riyanti, 2019).

Hasil penelitian yang dilakukan oleh Nonci (2018) memberikan kesimpulan bahwa keteladanan merupakan strategi yang baik dalam pembentukan karakter anak. Penelitian yang dilakukan oleh Munawwaroh (2019) membuktikan bahwa keteladanan merupakan cara yang paling utama dan paling efektif dalam pendidikan karakter. Lebih lanjut penelitian yang dilakukan oleh Masrur (2017) juga membuktikan bahwa keteladanan pengasuh (Kiai) memiliki peranan penting dalam pondok pesantren karena keteladannya mampu mempengaruhi masyarakat baik di lingkungan pondok pesantren maupun di luar pesantren.

Dengan demikian keteladanan pengasuh pondok pesantren memiliki peranan penting dalam pembentukan karakter peserta didik. Hal ini disebabkan setiap peserta didik dalam lingkungan pesantren cenderung memiliki keinginan untuk mencontoh pengasuhnya. Sehingga keteladanan pengasuh dapat memberikan pengaruh yang besar dalam pembentukan karakter para peserta didiknya.

Dari uraian di atas dapat disimpulkan bahwa pengasuh dan orang tua dapat berperan dalam membentuk karakter santri. Dengan demikian penelitian ini bertujuan untuk mengetahui bagaimana peran orang tua dan keteladanan pengasuh di pondok pesantren Tarbiyatul Athfal Tegalrejo Magelang dalam membentuk karakter santri

\section{METODE}

Guna menjawab penelitian ini maka pendekatan yang digunakan adalah pendekatan kualitatif dengan jenis studi kasus (Mulyana, 2013). Pendekatan kualitatif digunakan dalam penelitian ini karena fleksibel, dinamis dan eksploratif (Nugrahani, 2014). Data penelitian menggunakan data primer, yaitu data yang dikumpulkan secara langsung oleh peneliti (Purwanto, 2018). Data penelitian dikumpulkan dengan teknik wawancara mendalam dan observasi. Alat pengumpulan data berupa panduan wawancara dan pedoman observasi. Narasumber yang menjadi sasaran penelitian yaitu satu pengasuh, 3 Orang Wali Santri, dan 3 pengurus pesantren. 
Lokasi penelitian adalah Pondok Pesantren Tarbiyatul Athfal Kecamatan Tegalrejo Kabupaten Magelang. Pemilihan lokasi ini berdasarkan pertimbangan bahwa Pondok Pesantren Tarbiyatul Athfal merupakan pondok yang berdiri dan berkembang di era milenial dengan usia santri yang relatif muda sehingga untuk dilakukan penelitian pembentukan karakter. Waktu penelitian tiga bulan yaitu dari bulan Juni sampai bulan Agustus 2020. Data-data yang berhasil dikumpulkan kemudian dianalisis secara interaktif, sehingga teknik analisis data pada penelitian ini menggunakan model interaktif. Model interaktif terdiri atas pengumpulan data, reduksi data, penyajian data, dan penarikan kesimpulan (Sugiyono, 2017). Secara ringkas Teknik analisis data dapat digambarkan pada gambar 1 berikut:

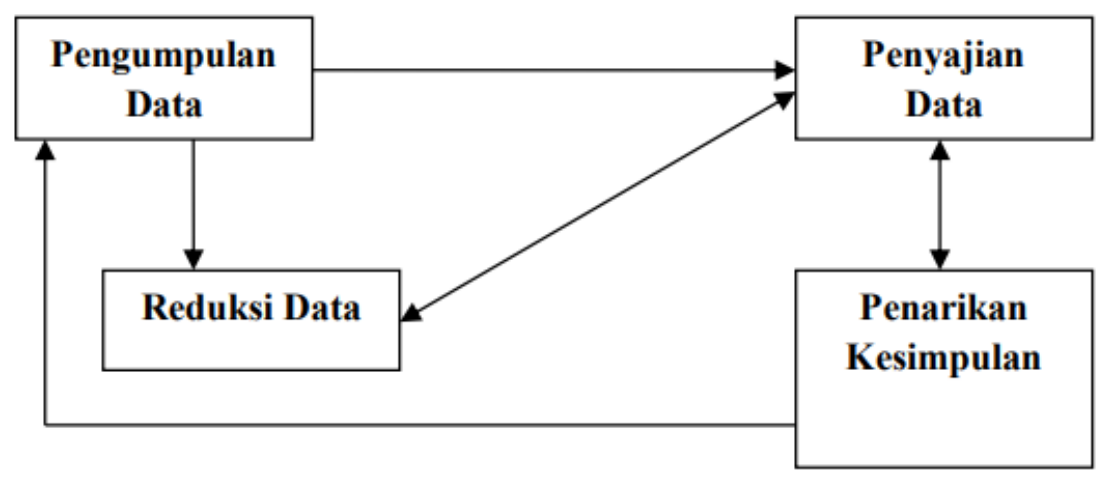

Gambar 1 Model Analisis Interaktif

Pengumpulan data, merupakan tahapan pertama dalam analisis data (Idrus, 2009). Pengumpulan data pada penelitian ini dilakukan dengan wawancara, observasi dan dokumentasi. Data-data yang telah dikumpulkan kemudian dilakukan reduksi data. Reduksi data pada dasarnya upaya peneliti untuk menyaring data yang telah dikumpulkan. Reduksi data penting dilakukan karena data-data penelitian diperoleh dari lapangan cukup banyak jumlahnya (Sugiyono, 2018). Oleh karena itu peneliti perlu mereduksi data-data yang telah diperoleh di lapangan. Dengan dilakukan reduksi maka peneliti akan dimudahkan dalam proses analisis data, karena data-data yang direduksi adalah data-data yang sesuai dengan kebutuhan analisis data.

Tahap selanjutnya adalah penyajian data. Penyajian data merupakan tahapan selanjutnya setelah proses reduksi data. Pada tahapan ini peneliti menyajikan datadata yang telah direduksi, sehingga data-data yang disajikan pada dasarnya adalah data-data yang telah dipilih/dipilah oleh peneliti. Reduksi data sangat membantu untuk mengedit data, meringkasnya, dan membuat data penelitian lebih rapi (Mezmir, 2020). Data-data yang disajikan akan memudahkan dalam proses penarikan kesimpulan dan juga memudahkan para pembaca dalam memahami hasil penelitian. Setelah menyajikan data, tahap selanjutnya dalam analisis interaksi model adalah penarikan kesimpulan. Penarikan kesimpulan didasarkan pada hasil pengumpulan data, reduksi dan penyajian data. Penarikan kesimpulan dalam penelitian ini juga didasarkan pada tanggapan para narasumber penelitian, hasil observasi dan data-data yang dikumpulkan melalui dokumentasi. Dengan penarikan kesimpulan tidak bersifat subjektif dari peneliti, namun berdasarkan fakta-fakta yang diperoleh pada saat penelitian. 


\section{HASIL DAN PEMBAHASAN}

\section{Keteladanan Pengasuh dalam Pembentukan Karakter Santri}

Dari hasil penelitian diperoleh hasil bahwa teladan yang diberikan dalam pembentukan karakter yaitu dengan keteladanan dalam menegakkan aturan. Sebagaimana lembaga pendidikan pada umumnya, pondok pesantren Tarbiyatul Athfal juga memiliki sejumlah peraturan yang harus dipatuhi. Melalui aturan-aturan yang berlaku jelaslah bahwa pondok pesantren Tarbiyatul Athfal telah berupaya membentuk karakter para santrinya. Aturan tersebut setidaknya memuat aspek kerapian, kesopanan, ketertiban, kedisiplinan, dan kecakapan dalam perbuatan maupun perkataan. Agar semua santri mematuhi aturan tersebut maka para pengasuh harus memberi contoh terlebih dahulu. Hal ini disadari oleh pengurus pondok pesantren Tarbiyatul Athfal bahwa ketika sudah masuk ke lingkungan pesantren, secara otomatis semua stakeholder harus mengikuti peraturan. Segala perbuatan atau perkataan pengasuh menjadi pandangan dan tuntunan bagi santri yang melihatnya, apalagi tinggal dalam satu lingkungan. Bagi para santri yang relatif masih kecil, maka meniru atau mencontoh adalah hal yang mudah. Oleh sebab itu, dalam pembentukan karakter santri melalui keteladanan pengasuh cukup hanya dengan memberi contoh yang baik dan benar.

Narasumber penelitian menyatakan bahwa salah satu teladan yang dapat diambil dari pengasuh adalah kedisiplinannya dalam melaksanakan salat fardhu secara berjamaah. Pengasuh melatih dan membimbing para santri bukan saja hanya dalam teori-teori fikih semata. Pengasuh pun tampil memberi keteladanan dengan cara menjadi "imam Salat" lima waktu dengan tingkat kedisiplinan yang ketat. Dengan demikian santri dapat meneladani pengasuh dalam hal kedisiplinan dalam melaksanakan salat lima waktu.

Keteladanan tidak hanya diterapkan pada pengasuh selaku pimpinan tertinggi pondok pesantren, namun juga para pengurus. Pengurus pondok pesantren Tarbiyatul Athfal sebagai pelaksana kegiatan di pondok pesantren juga berperan besar dalam pembentukan karakter para santri. Pengurus memiliki fungsi sebagai jembatan pelaksana kegiatan di lingkungan pesantren Tarbiyatul Athfal. Narasumber penelitian menyampaikan bahwa para pengurus juga memberikan teladan kepada para santri seperti apabila sedang berjalan dan berpapasan dengan pengasuh, maka para pengurus akan berhenti, membungkukkan badan. Bahkan pada saat menghadap pengasuh maka para pengurus akan berjongkok. Pengurus juga akan mencium tangan pengasuh saat berjabat tangan. Dalam contoh ini ditanamkan oleh pengasuh, hal ini bukan menghormati secara fisik, tetapi menghormati 'ilmu' yang ada pada sosok pengasuh.

Dari hasil penelitian yang dilakukan keteladanan pengasuh dalam pembentukan karakter santri dilakukan dengan dua cara yaitu keteladanan langsung kepada pengasuh pondok pesantren dan keteladanan melalui pengurus (tidak langsung). Baik keteladanan langsung maupun tidak langsung pada dasarnya adalah upaya yang dilakukan agar para santri memiliki karakter sebagaimana tercermin dalam kitab ta'lim muta'allim, seperti 1) rasa hormat, 2) sabar dan tabah, 3) kerja keras, 4) sederhana dan 5) tawakal.

Rasa hormat kepada orang lain terutama kepada pengasuh atau guru merupakan aspek yang penting untuk ditekankan (Mohune, 2017). Dengan demikian rasa hormat merupakan sebuah kewajiban bagi setiap santri di pesantren Tarbiyatul Athfal, karena berkah tidaknya ilmu yang didapat tergantung dari rasa hormatnya kepada pengasuh atau gurunya. Jika santri menunjukkan akhlak-akhlak terpuji kepada pengasuh maka akan terjalinlah hubungan baik yang melahirkan sikap saling pengertian, cinta damai, dan rasa kasih sayang ('Aliyah \& Amirudin, 2020). 
Sabar dan tabah adalah bentuk keteladanan yang selalu ditekankan oleh pengasuh. Sabar adalah sikap yang tahan terhadap cobaan yang diberikan Allah kepadanya atau kepada hamba-Nya ('Aliyah \& Amirudin, 2020). Belajar merupakan upaya untuk melahirkan kebenaran, oleh karena itu ketabahan dan kesabaran mutlak diperlukan (Mohune, 2017). Dengan kesabaran itulah para santri di pesantren Tarbiyatul Athfal akan terjaga dari kemaksiatan, konsisten menjalankan ketaatan, dan tabah dalam menghadapi berbagai macam cobaan. Dalam menuntut ilmu, kesabaran dan ketabahan sangan penting dimiliki oleh setiap santri, karena dengan sikap sabar dan tabah inilah yang nantinya akan melahirkan sikap kerja keras agar tujuan yang hendak diraih dapat terwujudkan.

Kerja keras dapat diartikan Kerja keras yaitu perilaku yang menunjukkan upaya sungguh-sungguh dalam mengatasi berbagai hambatan belajar dan tugas serta menyelesaikan tugas dengan sebaik-baiknya (Asnawi, 2015). Kerja keras dapat dilakukan dalam segala hal, termasuk dalam menuntut ilmu. Maka dari itu, para santri di pesantren Tarbiyatul Athfal wajib bekerja keras dalam menuntut ilmu agar tujuan maupun cita-cita dari penuntut ilmu dapat terpenuhi dan terealisasikan. Salah satu wujud kerja keras yang dicontohkan pesantren Tarbiyatul Athfal adalah dengan konsisten belajar dan mengulangi pelajaran yang telah diajarkan kepadanya, karena dengan mengulangi pelajaran maka ilmu yang didapat akan semakin hafal serta mudah dalam memahaminya. Hal ini sejalan dengan nilai pendidikan karakter di Indonesia yang menekankan nilai disiplin, nilai kerja keras, nilai mandiri, nilai menghargai prestasi, nilai gemar membaca, dan nilai tanggung jawab.

Sederhana pada dasarnya adalah salah satu contoh atau teladan dari Rasulullah SAW (Ardianto, 2020). Dengan hidup sederhana maka akan semakin dekat dengan Allah. Contoh dari perilaku hidup sederhana yang ditekankan oleh pengasuh pesantren Tarbiyatul Athfal adalah menghindari perut kenyang, banyak tidur, dan banyak bicara. Dengan demikian sederhana merupakan sifat yang mencerminkan akhlak mulia yaitu berhati-hati dalam memilih dan memilah apa yang berhubungan dengan pakaian, makanan, bahkan lingkungan perlu diperhitungkan keberadaannya.

Tawakkal adalah suatu sikap mental seorang yang merupakan hasil dari keyakinannya yang bulat kepada Allah (Rika, Fahrudin, \& Sumarna, 2020). Di pesantren Tarbiyatul Athfal, penting bagi para santri untuk memiliki sikap tawakal, karena dengan bersikap tawakal maka dia telah meyakini bahwa Allah SWT ridho terhadap usahanya atau tidak. Dengan bersikap tawakal ini maka akan membentuk karakter santri berupa memegang nilai religius.

Karakter dapat di bangun melalui keteladanan pengasuh atau kiayi di Lembaga pendidikan berbasis pesantren. Seorang pengasuh memiliki kontribusi besar dalam pembentukan karakter santrinya, karena santri cenderung mengikuti apa yang dilihat dari pengasuhnya. Keteladanan menjadi titik sentral dalam mendidik dan membina karakter santri, jika pengasuh memberikan contoh yang baik, maka para santrinya juga akan berbuat baik, Dengan demikian keteladanan pengasuh akan menjadi metode yang tepat dalam membina karakter santri (Rizal, lqbal, \& Najmuddin, 2018).

Pembentukan karakter peserta didik melalui keteladanan pengasuh tepat untuk dilakukan, karena kehidupan dipesantren secara tidak langsung melaksanakan pendidikan karakter. Contoh yang paling nyata dapat dilihat dari berbagai aturan yang diterapkan di pesantren. Pengasuh adalah satu-satunya sentra yang menjadi teladan bagi para santrinya dalam pembentukan karakter. Beberapa teladan yang diberikan pengasuh dalam pendidikan karakter diantaranya adalah disiplin. Jika pengasuh memberikan contoh untuk selalu disiplin maka peserta didik akan tepat waktu dalam beribadah, tidak terlambat untuk datang ke sekolah, tidak pernah absen/tidak masuk kelas tanpa keterangan, tepat waktu mengerjakan dan mengumpulkan tugas sekolah, keluar masuk kelas minta izin guru, menaati kontrak belajar, role of class, peraturan pesantren, dan selalu memakai seragam sesuai jadwal (Prasetyo, 2016). 
Dalam tradisi pesantren pengasuh atau dikenal dengan kiai, pada dasarnya memiliki lima peran utama yaitu sebagai guru ngaji, sebagai tabib, sebagai rois atau imam, sebagai pengasuh dan pembimbing, sebagai motivator dan sebagai orang tua kedua (Dhofier, 2015). Dari kelima peran inilah pengasuh pada dasarnya menjadi figur sentral dalam pembentukan karakter santri. Dalam upaya membentuk karakter ini, maka pengasuh memberikan sejumlah teladan yang dapat ditiru oleh para santri. Dalam teori belajar behaviorisme, belajar merupakan proses perubahan tingkah laku sebagai akibat dari interaksi antara stimulus dan respons yang salah cirinya adalah menekankan peranan lingkungan (Pratama, 2019). Dengan demikian pembentukan karakter santri melalui keteladanan sejalan dengan teori belajar behaviorisme. Dengan teori ini maka pengasuh pesantren Tarbiyatul Athfal sebagai bagian dari lingkungan pesantren akan menjadi stimulus bagi para santri untuk kemudian meresponnya dengan meniru tindakan pengasuh pesantren Tarbiyatul Athfal.

Hasil penelitian ini sejalan dengan penelitian yang dilakukan oleh Zurqoni, Retnawati, Arlinwibowo, \& Apino (2018), yang juga membuktikan bahwa salah satu aspek yang penting dalam pendidikan karakter adalah dengan keteladanan. Demikian halnya dengan penelitian yang dilakukan oleh Sa'diyah (2018) bahwa untuk menanamkan pendidikan karakter pada peserta didik, beberapa metode perlu dikuasai oleh pendidik, seperti perumpamaan, keteladanan, pembiasaan, mauidhah, targhib dan tarhib. Dengan beberapa metode tersebut, seorang pendidik tidak hanya dapat memberikan pengetahuan, tetapi juga menginternalisasikan nilai-nilai spiritual pada peserta didiknya

\section{Peranan Orang Tua dalam Pembentukan Karakter Santri}

Orang tua memiliki peranan yang besar dalam pembentukan karakter santri di pondok pesantren Tarbiyatul Athfal. Peran tersebut pada dasarnya berkaitan erat dengan penegakan peraturan pondok pesantren yang melarang orang tua santri untuk sering melakukan kunjungan. Narasumber penelitian menyatakan bahwa orang tua tidak terlalu sering menjenguk anaknya dan mengikuti apa yang telah menjadi kebijakan pondok pesantren Tarbiyatul Athfal. Jika orang tua menghendaki anaknya untuk tinggal di pondok pesantren Tarbiyatul Athfal dengan tujuan agar dari segi karakter maupun ilmu agamanya dapat terjamin, maka orang tua juga harus melakukan ketentuan yang telah ditetapkan oleh pondok pesantren Tarbiyatul Athfal.

Pondok pesantren Tarbiyatul Athfal pada dasarnya tidak melarang orang tua untuk mengunjungi putra putrinya, namun ada jadwal khusus yang telah ditentukan kapan waktu kunjungan dapat dilakukan. Pembatasan kunjungan ini secara eksplisit dapat membentuk karakter santri berupa kesabaran dan kedisiplinan. Kesabaran terkait dengan keinginan untuk bertemu dengan orang tuanya, kedisiplinan terkait dengan kepatuhan santri terhadap peraturan yang telah ditentukan oleh pondok pesantren.

Orang tua juga masih berperan penting dalam pembentukan karakter santri pada saat berada di lingkungan keluarga. Selain dengan metode keteladanan, orang tua juga menggunakan metode pembiasan. Narasumber penelitian menyatakan bahwa pada saat anak-anak pulang ke rumah maka kebiasaan-kebiasaan baik yang bisa dilakukan pada saat di pondok juga diterapkan di rumah. Pembiasaan yang dilakukan oleh orang tua seperti melaksanakan salat tepat waktu, menundukkan pandangan pada saat berbicara dengan orang yang lebih tua, tidak bicara kasar dan lain sebagainya. Jika para santri tidak melakukan salat tepat waktu maka orang tua akan memberikan teguran dengan ucapan yang lembut dengan menyatakan di pondok sudah diajarkan tepat waktu, maka di rumah harus demikian. Dengan demikian peran orang tua dalam hal pembiasaan ini dilakukan pada saat santri berada di rumah. 
Narasumber (orang tua santri) menyatakan bahwa kesulitan yang dihadapi oleh orang tua dalam membentuk karakter melalui pembiasaan ini adalah santri merasa bahwa salat tepat waktu dan tidak berbicara kasar hanya berlaku di pondok saja, sedangkan di rumah tidak diperlukan. Selain itu santri banyak berhubungan dengan orang lain pada saat di rumah, sehingga adakalanya santri mengeluarkan kata-kata kasar yang diperoleh dari teman-temannya di luar rumah. Hal ini menunjukkan bahwa pembentukan karakter melalui pembiasaan sulit dilakukan, karena adanya interaksi santri dengan lingkungan yang tidak mendukung pembiasaan-pembiasaan baik yang telah dilaksanakan di pondok.

Dari hasil penelitian di atas dapat ditunjukkan bahwa, kendati para santri sudah "dititipkan" di pondok pesantren, orang tua juga masih memiliki peran yang penting. Dengan demikian pandangan bahwa pondok pesantren layaknya "bengkel" yang dapat memperbaiki "kendaraan yang rusak" adalah kekeliruan. Kekeliruan ini pada akhirnya memunculkan anggapan bahwa setelah anaknya didaftarkan dan tinggal di pesantren maka lepaslah kewajiban orang tua atas anaknya (Azizah, 2013). Pandangan ini tentu saja keliru, karena orang tua tetap harus memberikan dukungan terhadap kebijakankebijakan yang diterapkan oleh pondok pesantren. Dengan demikian pembentukan karakter santri tidak akan dapat berjalan dengan baik tanpa adanya dukungan orang tua.

Dari uraian di atas maka orang tua juga memiliki peranan yang tidak kalah pentingnya dalam membentuk karakter santri pondok pesantren Tarbiyatul Athfal. Peran tersebut dapat dilakukan ketika santri berada di lingkungan pesantren dan ketika berada di rumah. Pada saat santri berada di lingkungan pesantren, maka orang tua dapat memberikan teladan berupa kepatuhan terhadap aturan pondok berupa tidak sering melakukan kunjungan. Dengan kepatuhan ini maka dapat membentuk karakter santri berupa kesabaran dan juga meneladani perilaku orang tuanya yang patuh terhadap aturan pondok pesantren. Adapun pada saat berada di rumah, orang tua juga berperan dalam pembentukan karakter dengan cara melanjutkan kebiasaan-kebiasaan baik yang telah dilakukan ketika berada di pondok pesantren.

Adanya larangan kunjungan orang tua dapat menumbuhkan karakter santri untuk bersabar (menahan diri) untuk tidak bertemu kedua orang tuanya dalam waktu tertentu. Terkait dengan kedisiplinan, batasan kunjungan orang tua dapat mendidik para santri agar dapat mematuhi segala aturan yang berlaku. Adanya aturan ini maka orang tua harus memberikan dukungan dengan tidak "mencuri-curi" waktu untuk melakukan kunjungan. Kepatuhan orang tua terhadap aturan ini pada dasarnya upaya orang tua untuk membentuk karakter santri dengan memberikan keteladanan. Hal ini sesuai dengan pendapat Taufiq \& Aminuddin (2016) bahwa dalam membentuk karakter dapat dilakukan dengan beberapa metode yaitu metode keteladanan, metode pembiasaan, pemberian nasihat, memberikan motivasi, pendekatan persuasif dan metode kisah.

Dengan demikian dalam rangka mendukung karakter santri di pondok pesantren Tarbiyatul Athfal orang tua telah berupaya untuk memberikan teladan berupa mematuhi aturan untuk tidak sering melakukan kunjungan putra-putrinya di luar jadwal yang ditentukan. Menurut Rizal et al., (2018) pembentukan melalui keteladanan lebih efektif untuk diterapkan karena santri akan meniru dan meneladani apa yang dilihat dari orang tuanya. Ketika orang tuanya patuh terhadap peraturan pondok pesantren maka santri atau putra-putrinya juga akan mengikuti orang tuanya (patuh terhadap aturan). Kepatuhan ini pada akhirnya dapat membentuk karakter santri berupa disiplin dan mematuhi aturan yang berlaku.

Pembiasaan pada dasarnya merupakan proses yang terus menerus untuk dilakukan oleh anak dapat berupa tingkah laku, pola pikir, keterampilan dan lain sebagainya (Taufiq \& Aminuddin, 2016). Kebiasaan seperti salat tepat waktu, menundukkan pandangan pada saat berbicara dengan orang tua, tidak bicara kasar 
dan lain sebagainya. Dengan demikian kebiasaan-kebiasaan yang dilakukan di pondok akan tetap dilanjutkan kendati santri sedang di rumah.

Hasil penelitian ini sejalan dengan hasil penelitian yang dilakukan oleh (Setiawan, Suparno, Sahabuddin, \& Ramadhan, 2020), yang membuktikan bahwa orang tua memiliki peranan yang besar dalam pendidikan karakter. Selain itu penelitian yang dilakukan oleh Hasanah \& Deiniatur (2019) juga membuktikan pentingnya peranan orang tua dalam pendidikan karakter. Pendidikan karakter harus dimulai dari keluarga melalui delapan fungsi keluarga yang meliputi, fungsi pendidikan, fungsi perlindungan, , fungsi ekonomi, dan fungsi rekreasi.

\section{SIMPULAN}

Hasil penelitian membuktikan bahwa pembentukan karakter santri dapat dilakukan oleh pengasuh pesantren Tarbiyatul Athfal melalui keteladanan. Keteladanan oleh pengasuh dilakukan dengan dua cara yaitu keteladanan langsung dan keteladanan tidak langsung. Baik keteladanan langsung maupun tidak langsung pada dasarnya adalah upaya yang dilakukan agar para santri memiliki karakter sebagaimana tercermin dalam kitab ta'lim muta'allim, yaitu seperti 1) rasa hormat, 2) sabar dan tabah, 3) kerja keras, 4) sederhana dan 5) tawakal. Adapun peran orang tua dalam pembentukan karakter dilakukan dalam dua kondisi, yaitu kondisi pada saat di lingkungan pesantren dan kondisi pada saat santri berada di lingkungan rumah. Pada saat santri berada di lingkungan pesantren, maka orang tua dapat memberikan teladan berupa kepatuhan terhadap aturan pondok berupa tidak sering melakukan kunjungan. Dengan kepatuhan ini maka dapat membentuk karakter santri berupa kesabaran dan juga meneladani perilaku orang tuanya yang patuh terhadap aturan pondok pesantren. Adapun pada saat berada di rumah, orang tua juga berperan dalam pembentukan karakter dengan cara melanjutkan kebiasaan-kebiasaan baik yang telah dilakukan ketika berada di pondok pesantren.

Dari simpulan penelitian ini maka keteladanan pengasuh dan orang tua memiliki peranan penting dalam pembentukan karakter santri pondok pesantren Tarbiyatul Athfal. Kendati demikian penelitian ini belum menggali lebih jauh mengenai bagaimana peran interaksi sosial dengan teman sebaya dalam pembentukan karakter santri. Interaksi dengan teman sebaya penting untuk dikaji, karena santri pada saat berada di lingkungan pesantren tidak hanya berhubungan dengan pengasuh dan pengurus pondok pesantren, tetapi dengan teman sebaya. Dengan demikian peneliti menyarankan agar penelitian selanjutnya melakukan analisis terhadap peran interaksi sosial dengan teman sebaya dalam pembentukan karakter santri.

\section{DAFTAR PUSTAKA}

'Aliyah, E., \& Amirudin, N. (2020). Konsep Pendidikan Akhlak dalam Kitab Ta'lim Muta'allim Karangan Imam Az-Zarnuji. TAMADDUN: Jurnal Pendidikan dan Pemikiran Keagamaan, 21(2), 161-181.

Antara. (2019). 30 Pelajar SMK Tawuran di Magelang, 1 Tewas, Hanya 3 Jadi Tersangka. Solo Pos. Diambil dari https://semarang.solopos.com/read/20190204/515/969614/30-pelajar-smktawuran-di-magelang-1-tewas-hanya-3-jadi-tersangka

Ardianto. (2020). Internalisasi Nilai Karakter Dalam Pembelajaran PAI Melalui Keteladanan Pendidik. Attaqwa: Jurnal IImu Pendidikan Islam, 16(1), 55-75.

Asnawi. (2015). Konsep Belajar Mengajar KH Hasyim Asy'ari dan Relevansinya dalam Penguatan Pendidikan Karakter Bangsa. Attanwir Jurnal Kajian Keislaman dan Pendidikan, 5(2), 10-20.

Azizah, N. (2013). Dukungan Orangtua bagi Anak yang Belajar di Pondok Pesantren. 
In Prosiding Seminar Nasional Parenting (hal. 132-141). Surakarta: Universitas Muhammadiyah Surakarta.

Departemen Pendidikan Nasional. (2010). Pendidikan Karakter Teori \& Aplikasi. Jakarta: Direktorat Jenderal Manajemen Pendidikan dan Menengah Kementerian Pendidikan Nasional.

Desforges, C., \& Abouchaar, A. (2003). The Impact of Parental Involvement, Parental Support and Family Education on Pupil Achievements and Adjustment: A Literature Review with. Research Report. Great Britain: Department for Education and Skills.

Dhofier, Z. (2015). Tradisi Pesantren. Jakarta: LP3S.

Elsap, D. S. (2018). Analisis Faktor yang Mempengaruhi Peningkatan Karakter dan Motivasi Belajar Anak Melalui Pendidikan Non Formal. Jurnal Pendidikan Nonformal, 13(2), 85-91.

Handayani, T., Soesilowati, E., \& Priyanto, A. S. (2018). Student Character Buliding Reconstruction Junior High School in District Galesong Takalar Based Values National Culture. Journal of Educational Social Studies, 7(2), 116-122.

Hasanah, U., \& Deiniatur, M. (2019). Character Education in Early Childhood Based on Family. Early childhood research journal (ECRJ), 2(1), 28-42.

Idrus, M. (2009). Metode Penelitian IImu Sosial. (Y. Sri, Ed.) (Kedua). Yogyakarta: Erlangga.

Koesoema, A. D. (2007). Pendidikan Karakter: Mendidik Anak di Zaman. Global. Jakarta: Grasindo. Jakarta: Grasindo.

Kosim, M. (2011). Urgensi pendidikan karakter. Karsa, 19(1), 1-8.

Kurniawan, A. (2015). Pendidikan Karakter di Pondok Pesantren dalam Menjawab Krisis Sosial. Edueksos: Jurnal Pendidikan Sosial dan Ekonomi, 4(2), 1-19.

Lickona, T. (2016). Educating for Character. Jakarta: Bumi Aksara.

Masrur, M. (2017). Figur Kyai dan Pendidikan Karakter di Pondok Pesantren. Tarbawiyah:Jurnal IImiah Pendidikan, 01(02), 272-282. Diambil dari http://ejournal.metrouniv.ac.id/index.php/tarbawiyah/article/view/1022

Mezmir, E. A. (2020). Qualitative Data Analysis: An Overview of Data Reduction, Data Display and Interpretation. Research on Humanities and Social Sciences, 10(21), 15-27. https://doi.org/10.7176/rhss/10-21-02

Mohune, T. (2017). Pembelajaran Akhlak Siswa Studi Implementasi Ajaran Kitab Ta'Lim Al-Muta'Allim. TADBIR: Jurnal Manajemen Pendidikan Islam, 5(1), 91-97.

Muhaimin, A. (2017). Strategi Pendidikan Karakter Perspektif Kh. Hasyim Asy'ari. Nidhomul Haq: Jurnal Manajemen Pendidikan Islam, 2(1), 26-37.

Mulyahati, B., \& Fransyaigu, R. (2018). Desain Inkuiri Moral dalam Pembentukan Karakter Nasionalis Siswa SD. DWIJA CENDEKIA: Jurnal Riset Pedagogik, 2(2), 10. https://doi.org/10.20961/jdc.v2i2.25644

Mulyana, D. (2013). Metodologi Penelitian Kualitatif: Paradigma Baru IImu Komunikasi dan IImu Sosial Lainnya. Bandug: Remaja Rosdakarya.

Munawwaroh, A. (2019). Keteladanan Sebagai Metode Pendidikan Karakter. Jurnal Penelitian Pendidikan Islam, 7(2), 141-156. https://doi.org/10.36667/jppi.v7i2.363

Nonci, M. H. (2018). Pembentukan Karakter Anak melalui Keteladanan. Sosioreligius, 3(2), 41-60. https://doi.org/10.24090/jk.v6i2.1933

Nugrahani, F. (2014). Metode Penelitian Kualitatif dalam Penelitian Pendidikan Bahasa. Solo: Cakra Books.

Prasetyo, D. (2016). Pembinaan Karakter Melalui Keteladanan Guru Pendidikan Kewarganegaraan di Sekolah Islam Al Azhar Yogyakarta. Jurnal Pendidikan Karakter, 6(2), 215-231.

Prasetyo, D., Marzuki, \& Riyanti, D. (2019). Pentingnya Pendidikan Karakter Melalui Keteladanan Guru. Harmony, 4(1), 19-32.

Pratama, Y. A. (2019). Relevansi Teori Belajar Behaviorisme Terhadap Pendidikan 
Agama Islam. Jurnal Pendidikan Agama Islam Al-Thariqah, 4(1), 39-49.

Purwanto. (2018). Teknik penyusunan instrumen uji validitas dan reliabilitas penelitian ekonomi syariah. Magelang: StaiaPress.

Rika, Fahrudin, \& Sumarna, E. (2020). Pendidikan Akhlak dalam Kitab Ta'lim alMuta'allim dan Implikasinya Terhadap Pembelajaran Pendidikan Agama Islam di Sekolah. Taklim:Jurnal Pendidikan Agama Islam, 1(1), 23-36.

Rizal, M., lqbal, M., \& Najmuddin. (2018). Model Pendidikan Akhlaq Santri di Pesantren dalam Meningkatkan Akhlaq Siswa di Kabupaten Bireuen. Nadwa: Jurnal Pendidikan Islam, 12(1), 89-116. https://doi.org/10.21580/nw.2018.12.1.2232

Rosikum. (2018). Peran Keluarga dalam Implementasi Pendidikan Karakter Religius Anak. Jurnal Kependidikan, 6(2), 293-308.

Sa'diyah, H. (2018). Internalization of Islamic Character Education to Students in Elementary School Plus Nurul Hikmah Pamekasan Madura. International Journal on Islamic Educational Research (SKIJIER), 2(1), 134-145.

Saihu, \& Rohman, B. (2019). Pembentukan Karakter Melalui Model Pendidikan Transformatife Learning Pada Santri di Pondok Pesantren Nurul Ikhlas Bali. Jurnal Pendidikan Islam, 08(02), 435-452.

Setiawan, J. A., Suparno, Sahabuddin, C. T., \& Ramadhan, S. (2020). The Role of Parents on the Character Education of Kindergarten Children Aged 5-6 Years in Bima. Universal Journal of Educational Research, 8(3), 779-784. https://doi.org/10.13189/ujer.2020.080307

Sugiyono. (2017). Metode Penelitian Kuantitatif, Kualitatif, dan R\&D. Bandung: Alfabeta.

Sugiyono. (2018). Metode Penelitian Pendidikan. Bandung: Alfabeta.

Syafe'i, I. (2017). PONDOK PESANTREN: Lembaga Pendidikan Pembentukan Karakter. Al-Tadzkiyyah: Jurnal Pendidikan Islam, 8(1), 61. https://doi.org/10.24042/atjpi.v8i1.2097

Taufiq, M. H., \& Aminuddin, F. (2016). Peran Orang Tua dalam Membangun Akhlak Anak Usia Dini. ThufuLA: Jurnal Inovasi Pendidikan Guru Raudhatul Athfal, 4(2), 118-137.

Zurqoni, Retnawati, H., Arlinwibowo, J., \& Apino, E. (2018). Strategy and Implementation of Character Education in Senior High Schools and Vocational High Schools. Journal of Social Studies Education Research, 9(3), 370-397. https://doi.org/10.17499/jsser.01008 